\title{
HMMR Gene
}

National Cancer Institute

\section{Source}

National Cancer Institute. HMMR Gene. NCI Thesaurus. Code C20757.

This gene plays a role in the mediation of motility, which effects migration and other cellular processes. 